\title{
EFEKTIFITAS PELATIHAN PARTISIPATORI INDUSTRI KREATIF BATIK TULIS
}

\author{
Suliyanto \\ Fakultas Ekonomi dan Bisnis, Universitas Jenderal Soedirman \\ suli_yanto@yahoo.com \\ Weni Novandari \\ Fakultas Ekonomi dan Bisnis, Universitas Jenderal Soedirman \\ Sri Murni Setyawati \\ Fakultas Ekonomi dan Bisnis, Universitas Jenderal Soedirman
}

\begin{abstract}
This study aims to analyze the effectiveness of training with a participatory approach in batik craft industry in Purbalingga. The subjects of this study are 20 batik artisans in Purbalingga. Data are collected by using focuss Group Discussion (FGD) and questionnaires. To analyze the differences between the perception of knowledge and skills of the trainees before and after the training, this study uses two different test average. Based on the result of analysis, there is an increase in the perception of knowledge and skills after training by using a participatory approach.
\end{abstract}

Keywords: participatory training, effectivenes, the perception of knowledge, the perception of skill

\begin{abstract}
ABSTRAK
Penelitian ini bertujuan untuk menganalisis efektifitas pelatihan dengan pendekatan partisipatori pada industri kerajinan Batik tulis di Purbalingga. Subyek penelitian ini adalah 20 pengrajin batik tulis di Purbalingga. Pengumpulan data dilakukan dengan menggunakan Focuss Discussion Group (FGD) dan kuesioner. Untuk menganalisis perbedaan persepsi pengetahuan dan perbedaan persepsi keterampilan peserta pelatihan sebelum dan sesudah mengikuti pelatihan dengan pendekatan partisipatori digunakan uji beda dua rata-rata. Berdasarkan hasil analisis terdapat peningkatan persepsi pengetahuan dan persepsi keterampilan setelah mengikuti pelatihan batik tulis dengan pendekatan partisipatori.
\end{abstract}

Kata kunci: pelatihan partisipatif, efektivitas, persepsi pengetahuan, persepsi ketrampilan

\section{PENDAHULUAN}

Batik telah diakui dunia menjadi satu representatif budaya tak-benda warisan manusia yang dimiliki oleh bangsa Indonesia (Antara News 2009). Ada beragam jenis batik yang ada di Indonesia, salah satunya adalah batik Purbalingga. Sentra kerajinan 
batik di Purbalingga tersebar di beberapa desa di wilayah Kabupaten Purbalingga, diantaranya Desa Dagan, Limbasari, Majapura, Galuh, Plembungan, Grecol, Gambar Sari, dan Selabaya. Suliyanto et al. (2014) menjelaskan, bahwa batik yang dihasilkan oleh pengrajin batik di Purbalingga adalah batik tulis. Batik tulis memiliki karakteristik yang berbeda dibanding dengan batik cap dan batik printing. Keterampilan membatik di Purbalingga diperoleh para pengrajin secara turun temurun dari orang tua mereka. Para pembatik tidak pernah mencoba dan juga tidak memiliki peralatan untuk membuat batik cap. Para pengrajin berpendapat bahwa mereka akan terus mempertahankan ciri khas batik tulis Purbalingga, karena di sinilah yang membedakan batik Purbalingga dengan batik lainnya.

Perkembangan batik tulis Purbalingga masih kalah bersaing dengan batik dari daerah lain seperti Pekalongan, Solo, dan Yogyakarta. Salah satu faktor utama yang menghambat adalah faktor sumber daya manusia (Suliyanto et al., 2010). Kendala pada faktor sumber daya manusia umumnya terkait dengan keterbatasan kualitas pembatik dan juga masalah regenerasi. Profil pengrajin batik di Purbalingga adalah mayoritas berjenis kelamin perempuan (90\%), dengan rentang usia 40-60 tahun, mempunyai tingkat pendidikan relatif rendah dan telah menekuni usaha batik lebih dari 10 tahun (Suliyanto, Wulandari, \& Novandari 2010). Faktor sumber daya manusia ini jika dirinci akan diketahui sub faktor kendala yang lebih spesifik. Sub faktor tersebut yaitu masih lemahnya manajerial pengelolaan usaha batik, tidak baiknya sistem regenerasi pengrajin batik untuk generasi muda, masih rendahnya produktivitas para pengrajin batik karena faktor usia, serta banyak munculnya industri padat karya di Purbalingga yang dianggap masyarakat lebih menjanjikan. Dinas Perindustrian Perdagangan dan Koperasi Kabupaten Purbalingga Suara Merdeka (2008) menjelaskan bahwa industri batik tulis Purbalingga saat ini menghadapi masalah regenerasi yang serius. Jumlah pengrajin batik tulis di Kabupaten Purbalingga terus mengalami penurunan dari tahun ke tahun. Jumlah pengrajin yang masih bertahan hingga saat ini kurang lebih sebanyak 395 orang pengrajin, yang mayoritas merupakan pengobeng atau buruh batik.

Dukungan dari pemerintah daerah saat ini sudah cukup banyak dalam upaya pengembangan usaha batik Purbalingga. Salah satu upaya untuk pengembangan UMKM batik dilakukan melalui kerja sama dengan perguruan tinggi dengan memberikan pelatihan. Pelatihan dinilai belum efektif dalam mengembangkan usaha batik Purbalingga. Pelatihan yang dilakukan adalah tentang teknik pembuatan batik untuk meningkatkan kemampuan dan keterampilan para pengrajin disertai dengan pemberian bantuan alat-alat membatik. Namun, realitanya semua upaya tersebut belum membuahkan hasil yang maksimal. Penyebabnya karena pelatihan yang selama ini dilakukan oleh pemda dan perguruan tinggi kurang efektif. Kurang efektifnya pelatihan yang selama ini dilakukan karena hanya bersifat top down. Agar hasil pelatihan lebih efektif, maka perlu adanya teknik pelatihan yang bersifat bottom up. Salah satu teknik pelatihan tersebut dikenal dengan pelatihan partisipatori, yaitu dengan melibatkan seluruh pemangku kepentingan dalam proses perencanaan, pelaksanaan, serta evaluasi hasil 
kegiatan pelatihan. Model ini diharapkan dapat memberikan hasil yang maksimal dalam upaya pengembangan dan pelestarian industri batik di Purbalingga.

Namun demikian efektifitas dari pelatihan partisipatori perlu diuji efektifitasnya. Efektifitas pelatihan dapat diukur dari peningkatan pengetahuan dan keterampilan tentang batik tulis dari para pengrajin sebelum dan sesudah mengikuti pelatihan dengan model partisipatori. Usaha untuk mengevaluasi bantuan pemerintah merupakan hal yang penting untuk dilakukan (Hartšenko \& Sauga 2013). Oleh karena itu, diperlukan adanya penelitian yang bertujuan untuk menganalisis efektifitas pelatihan partisipatori pada peningkatan usaha pada industri kreatif batik tulis di Purbalingga. Penelitian ini berguna sebagai dasar untuk meningkatkan efektifitas program pelatihan bagi pengrajin batik tulis, sehingga dapat meningkatkan kesejahteraan pengrajin batik dan menjaga kelestarian batik tulis sebagai salah satu warisan budaya bangsa Indonesia.

\section{KAJIAN PUSTAKA DAN PERUMUSAN HIPOTESIS}

Mathis dan Jackson (2006) menyatakan bahwa, pelatihan adalah suatu proses dimana orang-orang mencapai kemampuan tertentu untuk membantu mencapai tujuan organisasi, sedangkan Dessler (2010) adalah "Proses mengajarkan karyawan baru atau yang ada sekarang, keterampilan dasar yang mereka butuhkan untuk menjalankan pekerjaan mereka". Pelatihan merupakan salah satu usaha dalam meningkatkan mutu sumber daya manusia. Kemampuan (ability) merupakan suatu kapasitas individu untuk mengerjakan berbagai tugas dalam suatu pekerjaan (Robbins 2008). Oleh karena itu kemampuan yang dimiliki seorang individu sangat penting guna menunjang dalam mencapai tujuan organisasi.

Dari beragam model pelatihan, salah satunya adalah model pelatihan partisipatori. Model pelatihan partisipatori merupakan model pembelajaran yang menekankan pada proses pembelajaran, di mana kegiatan belajar dalam pelatihan dibangun atas dasar partisipasi aktif (keikutsertaan) peserta pelatihan dalam semua aspek kegiatan pelatihan, mulai dari kegiatan merencanakan, melaksanakan, sampai pada tahap menilai kegiatan pembelajaran dalam pelatihan. Upaya yang dilakukan pelatih pada prinsipnya lebih ditekankan pada motivasi dan melibatkan kegiatan peserta (Kamil 2003).

Beberapa teknik yang dapat dipergunakan dalam model pelatihan ini adalah: Teknik dalam tahap pembinaan keakraban meliputi teknik diad, teknik pembentukan kelompok kecil, teknik pembinaan belajar berkelompok, teknik bujur sangkar terpecah (broken square). Kemudian, teknik yang dipergunakan pada tahap identifikasi meliputi curah pendapat dan wawancara. Teknik dalam tahap perumusan tujuan meliputi teknik Delphi dan diskusi kelompok (round table discussion). Teknik pada tahap penyusunan program meliputi teknik pemilihan cepat ( $Q$-short technique) dan teknik perancangan program. Teknik yang dapat dipergunakan dalam proses pelatihan meliputi simulasi, studi kasus, cerita pemula diskusi (discussion starter story), buzz group, pemecahan masalah kritis, forum, role play, magang, kunjungan lapangan, dll. Teknik yang dapat 
dipergunakan dalam penilaian proses pelatihan, hasil dan pengaruh kegiatan meliputi respon terinci, cawan ikan (fish bowl technique) dan pengajuan pendapat tertulis. Sehingga menurut Lyton dan Pareek (1992) agar efektif, pelatihan merupakan tanggung jawab organisasi, peserta dan lembaga pelatihan serta didasarkan pada prinsip pembelajaran, terencana dengan baik dan di desain untuk merespon kebutuhan organisasi.

\section{Pengembangan Hipotesis}

Banyak penelitian sebelumnya yang telah meneliti tentang efektifitas pelatihan terhadap kinerja dari pegawai/perusahaan. Adanya program pelatihan diharapkan dapat meningkatkan kemampuan pegawai/perusahaan serta yang lebih penting adalah menunjang dalam tercapainya tujuan perusahaan. Penelitian dari Liang et al. (1995) menemukan hasil bahwa proses pelatihan yang dilakukan secara berkelompok ternyata lebih meningkatkan kinerja pegawai dalam hal pengetahuannya dibandingkan pelatihan secara individu. Hal itu dipengaruhi mediasi faktor kognitif dan juga hubungan sosial di dalam kelompok tersebut. Penelitian tersebut dilakukan pada 90 siswa dengan metoda eksperimen melakukan keterampilan dalam merangkai radio.

Hasil penelitian dari Bartlett (2001), menyimpulkan bahwa adanya pelatihan dapat meningkatkan sikap pegawai yang selanjutnya meningkatkan komitmennya dalam perusahaan/organisasi. Komitmen tersebut bisa dimoderasi dengan adanya kepuasan dari pegawai. Penelitian dilakukan kepada 337 perawat di rumah sakit. Penelitian dari Aragón et al. (2003), menemukan hasil bahwa terdapat pengaruh yang signifikan antara pelatihan terhadap kinerja, khususnya masalah efektifitas dan juga profitabilitasnya. Penelitiannya tersebut dilakukan pada sampel sebanyak 457 responden kelompok UKM di Eropa, meliputi Inggris, Belanda, Portugal, Finlandia dan Spanyol.

Penelitian berikutnya dari McNamara et al. (2012), menyatakan bahwa dengan adanya pelatihan secara positif meningkatkan kinerja organisasi/perusahaan, khususnya dalam hal tingkat produktivitas, inovasi dan turn over. Namun dilihat dari kelompok usia yang lebih tua ternyata memiliki tingkat konsentrasi yang lebih rendah selama menjalani proses pelatihan. Sampel penelitiannya adalah sebanyak 2.004 pegawai dari beragam jenis budaya di Eropa.

Berdasarkan uraian telaah pustaka tersebut dan hasil penelitian sebelumnya maka dapat dirumuskan hipotesis sebagai berikut:

H1: Terdapat peningkatkan pengetahuan pengrajin batik setelah mengikuti pelatihan dengan pendekatan partisipatori.

H2: Terdapat peningkatkan keterampilan pengrajin batik setelah mengikuti pelatihan dengan pendekatan partisipatori. 


\section{METODA PENELITIAN}

Penelitian ini merupakan penelitian ekperimental dengan subyek penelitian adalah 20 pengrajin batik tulis di Purbalingga dari total populasi pengrajian 395 pengrajin. Sampel dipilih dengan kriteria pengrajin yang memiliki tingkat pengetahuan dan keterampilan yang relatif sama. Untuk menentukan subyek penelitian agar memiliki tingkat pengetahuan dan ketrampilan yang relatif sama maka dipilih pengrajin yang memiliki masa kerja relatih sama dan pernah mengikuti pelatihan batik dengan jumlah dan materi pelatihan yang sama. Pengambilan data dilakukan dengan menggunakan Focus Discussion Group (FGD) dan kuesioner. FGD dilakukan untuk menentukan materi pelatihan, waktu pelatihan, lokasi pelatihan, pelatih, bahan dan alat yang dibutuhkan dan metoda pelatihan yang diinginkan oleh calon peserta pelatihan, sedangkan kuesioner digunakan untuk mengukur pesepsi tingkat pengetahuan dan persepsi tingkat keterampilan peserta pelatihan.

Alat analisis yang digunakan adalah uji beda rata-rata sampel berpasangan untuk menganalisis perbedaan persepsi tingkat pengetahuan dan keterampilan pengrajin batik tulis sebelum dan sesudah mengikuti pelatihan dengan pendekatan partisipatori. Suatu program pelatihan dikatakan efektif jika program pelatihan dapat meningkatkan pengetahuan dan ketrampilan peserta pelatihan, atau secara statistik dengan menggunakan uji beda rata-rata sampel berpasangan.

\section{ANALISIS DAN PEMBAHASAN}

Berdasarkan hasil observasi kepada 20 pengrajin batik di Purbalingga, diperoleh hasil tentang gambaran umum reseponden seperti terlihat pada Gambar 1. Berdasarkan ilustrasi tersebut dapat dilihat sebaran pengrajin batik berdasarkan jenis kelamin, usia, pendidikan, pengalaman membatik, frekuensi mengikuti pelatihan dan jenis pelatihan yang diikuti.

Dilihat berdasarkan jenis kelamin, dominasi pengrajin batik di Purbalingga adalah berjenis kelamin perempuan (90 persen). Hal ini dikarenakan selama ini pekerjaan membatik dipersepsikan sebagai pekerjaan yang memerlukan ketekunan, tidak memerlukan tenaga yang besar dan dapat dilakukan sebagai pekerjaan sampingan, sehingga lebih cocok untuk dilakukan oleh perempuan.

Selanjutnya, jika dilihat dari usia pengrajin diketahui bahwa rata-rata usia adalah 46,55 tahun, yang hal tersebut mengindikasikan bahwa usia tersebut termasuk kategori usia sudah tidak muda lagi. Melihat kondisi tersebut memang benar secara empiris diketahui bahwa masalah regenerasi merupakan hal penting bagi keberlanjutan usaha kerajinan batik tersebut.

Dilihat dari tingkat pendidikan, tidak ada dominasi yang signifikan dari para pengrajin. Hal ini relevan dengan beban kerja membatik yang tidak membutuhkan kualifikasi jenjang pendidikan minimal tertentu. Dari data terlihat bahwa jenjang 
pendidikan perguruan tinggi (PT) jumlahnya adalah yang paling sedikit sedangkan jenjang pendidikan SLTA adalah yang paling banyak. Hal tersebut dikarenakan karakteristik pekerjaan membatik masih berada pada level UMKM dan dalam bentuk industri rumah tangga sehingga tidak dibutuhkan kualifikasi pendidikan hingga jenjang PT, cukup dengan jenjang pendidikan SLTA selepas mereka menyelesaikan pendidikan dasar 12 tahun.

Tabel 1

Hasil Analisis Uji Beda Persepsi Pengetahuan Membatik

\begin{tabular}{lrr}
\hline & Setelah & \multicolumn{1}{c}{ Sebelum } \\
\hline Rata-rata & 5,324 & 3,818 \\
Varian & 0,022 & 0,060 \\
Jumlah Pengamatan & 10 & 10 \\
$D f$ & 18 & \\
$\mathrm{t}$ hitung & 16,625 & \\
$\mathrm{P}(\mathrm{T}<=\mathrm{t})$ satu-ujung & 0,000 & \\
$\mathrm{t}$ tabel satu-ujung & 1,734 & \\
\hline
\end{tabular}

Berdasarkan hasil analisis dengan menggunakan uji beda dua rata-rata diperoleh nilai t hitung $(16,625)$ lebih besar dibandingkan dengan t tabel $(1,734)$ dengan nilai $\mathrm{p}=0,000$ sehingga hipotesis yang menyatakan terdapat peningkatan persepsi pengetahuan pengrajin setelah mengikuti pelatihan batik tulis dengan pendekatan partisipatori diterima. Hal ini karena dengan mengikutsertakan pengrajin agar lebih aktif dalam proses pelatihan (pendekatan partisipatori), yaitu mulai dari tahap merencanakan hingga evaluasi, menjadikan apa yang diberikan dalam pelatihan sesuai dengan kebutuhan para pengrajin. Para pengrajin merasa bahwa pelatihan yang diberikan telah sesuai dengan apa yang mereka butuhkan, sehingga adanya proses transfer pengetahuan dalam pelatihan tersebut dapat lebih optimal dalam meningkatkan pengetahuan membatik dari para pengrajin itu sendiri. Kesesuaian tersebut bisa dilihat dari aspek pelatih, materi, metoda, alat dan bahan, waktu, lokasi dan peserta itu sendiri.

Tabel 2

Hasil Analisis Uji Beda Persepsi Keterampilan Membatik

\begin{tabular}{lcc}
\hline & Setelah & Sebelum \\
\hline Rata-rata & 5,006 & 3,665 \\
Varian & 0,046 & 0,115 \\
Jumlah Pengamatan & 10 & 10 \\
$D f$ & 18 & \\
$\mathrm{t}$ hitung & 10,567 & \\
$\mathrm{P}(\mathrm{T}<=\mathrm{t})$ satu-ujung & 0,000 & \\
$\mathrm{t}$ tabel satu-ujung & 1,734 & \\
\hline
\end{tabular}

Berdasarkan hasil analisis denga menggunakan uji beda dua rata-rata diperoleh nilai t hitung $(10,567)$ lebih besar dibandingkan dengan $t$ tabel $(1,734)$ dengan nilai 
$\mathrm{p}=0,000$ sehingga hipotesis yang menyatakan terdapat peningkatan persepsi keterampilan pengrajin setelah mengikuti pelatihan batik tulis dengan pendekatan partisipatori diterima. Hal ini karena dengan pendekatan partisipatori para pengrajin merasa bahwa program pelatihan yang dirancang telah sesuai dengan kondisi kemampuan/keterampilan mereka saat ini sehingga besar kemungkinan program yang dilaksanakan akan mampu meningkatkan keterampilan mereka dari sebelumnya. Aspek keterampilan menjadi poin penting tersendiri dalam usaha kerajinan batik agar semakin meningkat keterampilan yang dimiliki pengrajin maka akan semakin berkualitas hasil kerajinan batik mereka.

Hasil penelitian ini sejalan dengan Hufad et al. (2015), yang menyatakan bahwa Pendekatan pelatihan patisipatif lebih banyak dirasakan manfaatnya oleh peserta pelatihan dibandingkan dengan pendekatan yang lain, karena mayoritas peserta adalah orang dewasa.

\section{SIMPULAN, KETERBATASAN DAN SARAN}

Berdasarkan hasil analisis dan pembahasan terkait dengan efektifitas pendekatan pelatihan partisipatori pada industri kreatif batik tulis di Purbalingga, dapat disimpulkan hasil sebagai berikut:

1. Terdapat peningkatkan persepsi pengetahuan pengrajin batik setelah mengikuti pelatihan dengan pendekatan partisipatori.

2. Terdapat peningkatkan persepsi keterampilan pengrajin batik setelah mengikuti pelatihan dengan pendekatan partisipatori.

Penelitian ini memiliki beberapa keterbatasan yaitu adanya keterbatasan dalam mengendalikan tingkat pengetahuan dan ketrampilan peserta karena masing-masing peserta berasal dari beberapa sentra batik yang memiliki latar belakang yang berbeda sehingga memiliki persepsi pengetahuan dan ketrampilan yang berbeda pula. Rekomendasi untuk penelitian yang akan datang adalah sebagai berikut: 1). Perlu dilakukan penelitian lanjutan dengan menggunakan pengukuran obyektif dengan metoda pengumpulan data menggunakan metoda test, sehingga dapat meningkatkan obyektivitasnya 2). perlu dilakukan penelitian dimana pelatihan tidak hanya diukur dalam satu pelatihan saja, tetapi dilakukan penelitian dengan membandingkan antara penelitian dengan pendekatan non partisipatori dan pelatihan dengan pendekatan partisipatori.

\section{DAFTAR PUSTAKA}

Antara News. 2009. "UNESCO setujui batik sebagai warisan budaya Indonesia."

Aragón, María Isabel Barba, Antonio Aragón Sánchez, dan Raquel Sanz Valle. 2003. "Effect of training on business result." The International Journal of Human Resource Management 14 (6): 956-80.

Bartlett, Kenneth R. 2001. "The relationship between training and organizational 
commitment: A study in the health care field." Human Resource Development Quarterly 12 (4): 335-53. https://doi.org/10.1002/hrdq.1001.

Dessler, Gary. 2010. Manajemen Sumber Daya Manusia. 10ed. Jakarta: Indeks.

Hartšenko, J., dan A. Sauga. 2013. "The role of financial support in SME and economic evelopment in Estonia.” BEH-Business and Economic Horizons 9 (2): 10-22.

Hufad, A., J. S. Ardiwinata, dan Purnomo. 2015. "Penerapan model pelatihan partisipatif dalam meningkatkan kompetensi tenaga pendidik paud sebagai studi keilmuan mahasiswa konsentrasi pelatihan.” 2015.

Kamil, Mustofa. 2003. "Model-model pelatihan.” Academia. 2003.

Liang, D. W., R. Moreland, dan L. Argote. 1995. “Group versus individual training and group performance: The mediating role of transactive memory." Personality and $\begin{array}{lllll}\text { Social Psychology } & \text { Bulletin } & 21 & \text { (4): } & 384-93 .\end{array}$ https://doi.org/10.1177/0146167295214009.

Lyton, Rolf P., dan Udai Pareek. 1992. Pelatihan dan pengembangan tenaga kerja. 2ed. Jakarta: Karya Unipress.

Mathis, Robert L., dan John H. Jackson. 2006. Human Resource Management. Jakarta: Salemba Empat.

McNamara, Tay K., Emma Parry, Jungui Lee, dan Marcie Pitt-Catsouphes. 2012. "The effect of training on organizational performance: differences by age composition and cultural context." The International Journal of Human Resource Management 23 (6): 1226-44. https://doi.org/10.1080/09585192.2011.561253.

Robbins, Stephen P. 2008. Perilaku Organisasi. 12ed. Jakarta: Salemba Empat.

Suara Merdeka. 2008. "Batik warisan budaya nirgenerasi."

Suliyanto, Sri Murni Setyawati, Weni Novandari, dan Siti Zulaikha Wulandari. 2014. Batik tulis Purbalingga. Potensi, permasalahan, dan strategi pengembangan. Purwokerto: Universitas Jenderal Soedirman.

Suliyanto, Siti Zulaikha Wulandari, dan Weni Novandari. 2010. "Competitive strategy model of purbalingga batik: Analytical hierarchy process and quantitative strategic planning matrix approach.” Economic Journal of Emerging Markets 2 (2): 169-85. 